\title{
Carbon storage of Mediterranean grasslands
}

\author{
Piermaria Corona ${ }^{1}$, Emilio Badalamenti ${ }^{2}$, Salvatore Pasta ${ }^{2} \&$ Tommaso La Mantia ${ }^{2} *$ \\ ${ }^{1}$ Consiglio per la ricerca e la sperimentazione in agricoltura, Forestry Research Centre, Arezzo, Italy; piermaria.corona@unitus.it \\ ${ }^{2}$ Department of Agricultural and Forest Sciences, University of Palermo, Viale delle Scienze Ed. 4, I-90128 Palermo, \\ Italy; emilio.badalamenti@unipa.it; salvatore.pasta@ibbr.cnr.it; tommaso.lamantia@unipa.it
}

\begin{abstract}
Corona, P., Badalamenti, E., Pasta, S. \& La Mantia, T. 2016. Carbon storage of Mediterranean grasslands. Anales Jard. Bot. Madrid 73(1): e029.

Secondary grasslands are one of the most common vegetation types worldwide. In Europe, and in the Mediterranean basin, human activities have transformed many woodlands into secondary grasslands. Despite their recognized role in the global carbon cycle, very few data are available for estimating the biomass of Mediterranean grasslands. We developed linear regression models in order to predict the biomass of two native Mediterranean grasses (Ampelodesmos mauritanicus and Hyparrhenia hirta) and an invasive alien grass (Pennisetum setaceum). Ampelodesmos mauritanicus is very common throughout the Mediterranean basin, mostly on north-facing slopes, $H$. hirta characterizes thermo-xeric grasslands, while $P$. setaceum is an alien species that is rapidly spreading along coastal areas. The measured morphometric attributes of individual plants as potential predictors were considered. The validation results corroborate the ability of the established models to predict above ground and total biomass of $A$. mauritanicus and $P$. setaceum. We also evaluated the total biomass per hectare for each species. The highest biomass per hectare was found for $A$. mauritanicus, whereas biomass was higher for $H$. hirta than for $P$. setaceum. The replacement of $H$. hirta by $P$. setaceum may reduce the total carbon storage in the ecosystem; however, $P$. setaceum allocates more resources to the roots, thus increasing the more stable and durable pool of carbon in grasslands.
\end{abstract}

Keywords: Ampelodesmos mauritanicus, carbon storage, Hyparrhenia hirta, Mediterranean grasslands, Pennisetum setaceum.

\section{INTRODUCTION}

Grasslands are among the most widespread plant communities, being present on all continents except Antarctica, and covering about $24 \times 10^{6} \mathrm{~km}^{2}$ or nearly one-fifth of the planetary land area (Parton \& al., 1995; Scurlock \& Hall, 1998). According to the UNESCO (1973), grasslands are those areas where the coverage of woody species does not exceed $10 \%$ of their surface. In some regions of the world, mainly in Asia and North America, grasslands are often mature communities where the absence or near absence of woody species is related to local limiting factors. Elsewhere, and especially in Europe, where humans have greatly modified the landscape and have used lands that originally had woody cover for raising cattle and cultivating crops, most grasslands are considered secondary communities (Pärtel \& al., 2005; Zarovali \& al., 2007).

In the enlarged European Union (EU-25, with 25 member states), grasslands cover an estimated area of $0.57 \times$ $10^{6} \mathrm{~km}^{2}$ (15\% of the whole territory, cf. Ciais \& al., 2010). The FAO (2006), however, reported a reduction of almost $13 \%$ of the European grassland covering between 1990

\section{Resumen}

Corona, P., Badalamenti, E., Pasta, S. \& La Mantia, T. 2016. Almacenamiento de carbono en pastizales mediterráneos. Anales Jard. Bot. Madrid 73(1): e029.

Los pastizales secundarios son uno de los tipos de vegetación más comunes en todo el mundo. En Europa y en la cuenca mediterránea, las actividades humanas han transformado muchos bosques en pastizales secundarios. A pesar de su reconocido papel en el ciclo global del carbono, hay muy pocos datos disponibles para la estimación de la biomasa de los pastizales mediterráneos. Hemos desarrollado modelos de regresión lineal con el fin de predecir la biomasa de dos gramíneas nativas del Mediterráneo (Ampelodesmos mauritanicus e Hyparrhenia hirta) y otra exótica e invasora (Pennisetum setaceum). Ampelodesmos mauritanicus es muy común en toda la cuenca mediterránea, sobre todo en pendientes orientadas al norte, Hyparrhenia hirta es característica de pastizales termo-xerófilos, mientras que Pennisetum setaceum es una especie exótica que se está extendiendo rápidamente a lo largo de las zonas costeras. Se consideraron los caracteres morfométricos de plantas individuales como factores de predicción potenciales. Los resultados han corroborado la capacidad de los modelos establecidos para predecir la biomasa aérea total de $A$. mauritanicus y $P$. setaceum. También se ha medido y evaluado la biomasa total por hectárea de cada especie: la mayor fue la que correspondía a $A$. mauritanicus, mientras que la $H$. hirta fue mayor que la de $P$. setaceum. Así pues, la substitución de $H$. hirta por $P$. setaceum puede reducir el carbono almacenado en el ecosistema, sin embargo, $P$. setaceum asigna más recursos a las raíces, lo que implica un almacenaje de carbono más estable y duradero.

Palabras clave: almacenamiento de carbono, Ampelodesmos mauritanicus, Hyparrhenia hirta, pastizales mediterráneos, Pennisetum setaceum.

and 2003. This trend is due to the adoption of more intensive cultivation techniques with relatively high environmental impact (Bonanomi \& al., 2006) or, conversely, to the social and economic marginalization of the least accessible areas and the abandonment of traditional agro-pastoral activities, resulting in an encroachment by woody species. oodlands, in contrast, have increased their covering in all European countries between 1960 and 2010 (Young \& al., 2005; FRA, 2010) because of their increased protection resulting from conservation efforts and, as noted earlier, because of the spontaneous colonization (secondary succession) of abandoned pastures and grasslands. Similar trends have been recorded between 1990 and 2008 in Italy, where grassland covering decreased by $14 \%$, while woodlands increased by $5.6 \%$ (Corona \& al., 2012).

Grasslands contain a wide range of annual and perennial herbaceous species, and are among the most speciesrich communities of semi-natural ecosystems. Because many plants and animals are exclusively linked to such habitats, grasslands have a prominent biogeographical and conservation value ( allis de Vries \& al., 2002; Grill \& al., 2005;

\footnotetext{
* Corresponding author
} 
Pärtel \& al., 2005; Öckinger \& Smith, 2007). Most temperate and Mediterranean European grasslands have a secondary origin, and the intensity and frequency of human disturbance, together with the heterogeneous pedoclimatic conditions of European countries, have generated local grassland communities that differ substantially in structure and species composition (Tuba \& Kaligarič, 2008). Nevertheless, the recovery and long-term preservation of these precious semi-natural environments generally depend on regulated forms of human disturbance (e.g., controlled grazing and prescribed burning) that block succession and support a permanent herbaceous community at the expense of woody species (Barbaro \& al., 2001; allis de Vries \& al., 2002; Bonanomi \& al., 2006). In other words, grassland management requires more than protection. In particular, extensive grazing is recommended for the long-term maintenance of grassland habitats and species ( illems, 1983; Pykälä, 2003; Öckinger \& Smith, 2007). According to NoyMeir \& Oron (2001), grazing is an essential tool for conserving the native flora of Mediterranean ecosystems. That grazing is feasible and desirable even within protected areas has been demonstrated in Spain (Verdú \& al., 2000) and in the Czech Republic (Dostálek \& Frantík, 2008). In addition to ensuring the preservation of habitats, moderate grazing of Alpine, temperate, and Mediterranean grasslands also benefits plant species richness (i.e., plant species richness is greater in moderately grazed grasslands than in abandoned areas or in grasslands that have not been grazed for several years; Puerto \& al., 1990; Noy-Meir, 1995; Pucheta \& al., 1998; Harrison \& al., 2003; Pykälä, 2004; Bonanomi \& al., 2006).

Grasslands also play an important role in the global carbon cycle (Parton \& al., 1995), particularly as a consequence of carbon sequestration in soil (Ciais \& al., 2010). The carbon stored in grassland soils represents a rather stable carbon pool (Hungate \& al., 1997). Researchers have estimated that terrestrial ecosystems can absorb about one third of the anthropogenic emissions of greenhouse gases (Scurlock \& Hall, 1998; Janssens \& al., 2003) and may thus help mitigate ongoing climate change. The Earth's grasslands, including tropical savannas, represent approximately $20 \%$ of the total terrestrial biomass (Scurlock \& Hall, 1998; Robinson, 2007) and contain in their soils at least $28 \%$ of the global stock of carbon (Robinson, 2007) and $12 \%$ of the soil organic matter (SOM; Jones, 2010). Even in the European Community in general, and in Italy in particular, grasslands are an important terrestrial carbon pool and, although they may be sources of greenhouse gases (e.g., methane and nitrogen oxides), they generally represent a net carbon sink as important as that of forest ecosystems (Janssens \& al., 2005; Gilmanov \& al., 2007; Ciais \& al., 2010).

The efforts to restore degraded and overexploited grasslands, which aim to recover biodiversity and ecosystem functions, also increase carbon sequestration in the soil and improve soil structure (De Deyn \& al., 2011). The restoration and maintenance of degraded grassland by humans may reduce the potential for carbon sequestration that would come about should succession have been allowed to proceed.

In the first and experimental part of this study, we developed predictive models for the aboveground (ag) and belowground (bg) biomass of Ampelodesmos mauritanicus (Poir.) T. Durand \& Schinz, Consp. Fl. Afric. 5: 874 (1894) [Arundo mauritanica Poir., Voy. Barbarie 2: 104 (1789), basion.], Hyparrhenia birta (L.) Stapf in Oliv., Fl. Trop. Afr. 9: 315 (1919) [Andropogon birtus L., Sp. Pl.: 1046 (1753), basion.], and Pennisetum setaceum (Forssk.) Chiov. in Boll. Soc. Bot. Ital. 1923: 113 (1923) [Phalaris setacea Forssk., Fl. Aegypt.-Arab.: 17 (1775), basion.].

hile substantial data are available for estimating the biomass of trees and shrubs, very few data exist for Mediterranean herbaceous perennials. Filling this knowledge gap is an important objective of this research, in which those grasslands dominated by $A$. mauritanicus and H. hirta on the island of Sicily (Italy) are considered a case study.

\section{MATERIAL AND METHODS}

\section{Studied localities}

The study was conducted in the two nature reserves of Cape Gallo and Mount Pellegrino in Palermo Province, and in the afforested area of Mount Inici in Trapani Province. These three places share the same bedrocks (which is mostly characterized by limestones and marls prone to karstic processes), the same soil associations, as well as the same natural landscapes (steep slopes with shallow soils mostly covered by perennial grasslands) (Table 1).

\section{Grassland species}

The main ecological and biological features of the three caespitose grasses considered in this study are described in the following paragraphs. Unless stated otherwise, the information is also provided by Pasta \& al. (2010).

Table 1. Main characteristics of the three studied localities.

\begin{tabular}{lccc}
\hline & Cape Gallo & Mount Pellegrino & Mount Inici \\
\hline Altitude (m.a.s.l.) & 40 & 85 & 500 \\
Bedrock & limestones & limestones & limestones and marls \\
Soil association (USDA classification) & lithosoils-rock outcrops-terra rossa & lithosoils-rock outcrops-terra rossa & lithosoils-rock outcrops-terra rossa \\
Average mean annual temperature $\left({ }^{\circ} \mathrm{C}\right)$ & 20 & 20 & 16.5 \\
$\begin{array}{l}\text { Average annual rainfall }(\mathrm{mm}) \\
\begin{array}{l}\text { Bioclimate according to Rivas-Martínez's } \\
\text { classification }\end{array}\end{array}$ & 645 & 611 & 680 \\
\hline
\end{tabular}

Data on soils were obtained from Fierotti (1988), and information on local climate and bioclimate was obtained from Drago \& al. (2002). 


\section{Ampelodesmos mauritanicus (Mediterranean tussock grass)}

It is a native $C_{3}$ tussock grass. It reaches $1 \mathrm{~m}$ in height and is very common throughout the coastal and hilly areas of the Mediterranean basin, from the Iberian Peninsula to Greece, including Northern Africa. Perennial grasslands that include A. mauritanicus are one of the most widespread vegetation types in Sicily. Although they generally represent a stage of degradation of the local forest communities, they should be considered as a stable and lasting "disclimax" (Minissale, 1995). The floristic richness of these grasslands may vary greatly among sites according to the frequency and intensity of human disturbance. They occupy most slopes from sea level up to 1,200 m.a.s.l. (Minissale, 1995) and are especially localized on steep and north-facing slopes within the meso-Mediterranean and also thermo-Mediterranean belt (Brullo \& al., 2010). However, A. mauritanicus shows an effective drought resistance (Mingo \& Mazzoleni, 1997). Ampelodesmos mauritanicus grasslands are considered important habitats in European countries and have therefore been included in the Council Directive 92/43/ EEC (EC, 1992) on the conservation of natural habitats and of wild fauna and flora, hence requiring a special protection regime. This caespitose grass is commonly found in areas characterized by moderate and frequent grazing, and its considerable post-fire vegetative regrowth, coupled with its increased seed production in burned areas (Vilà \& al., 2001), make it extremely well adapted to post-fire colonization and therefore important for control of water erosion.

\section{Hyparrhenia hirta (Coolatai grass)}

It is a native $\mathrm{C}_{4}$ perennial grass that normally grows up to $30-60 \mathrm{~cm}$. Its wide natural distribution includes southern Africa and the Mediterranean region, but this perennial grass is now naturalized in many other countries and is considered a serious invader of native pastures in Australia (McArdle \& al., 2004). In Sicily, thermo-xeric grasslands with $H$. hirta occur in coastal environments from sea level up to 600 m.a.s.l., mostly in extremely arid environments on poorly developed and shallow soils of the thermo-Mediterranean belt (Brullo \& al., 2010). In particular, these grasslands represent a typical stage of degradation of the sclerophyllous scrub formations belonging to the phytosociological order Quercetalia calliprini Zohary. Because its seeds can germinate over a wide range of environmental conditions (Chejara \& al., 2008), seedling emergence and establishment mainly depend on the number of seeds produced and on biotic and abiotic factors (Chejara \& al., 2008). The progressive reduction of $H$. hirta on north-facing slopes and with increasing altitude has been attributed to the low germination rate and the limited resistance of its seedlings to low temperatures (Litav, 1972), especially to temperatures below $15{ }^{\circ} \mathrm{C}$ (Mc illiam \& al., 1970). Apart from facing summer drought, this native grass tolerates or is favoured by frequent and intense human disturbance (e.g., fire and grazing).

\section{Pennisetum setaceum (Fountain grass)}

It is a non-native $C_{4}$ grass that grows up to $30-100 \mathrm{~cm}$. Although it is native to Northern Africa and the Middle East, $P$. setaceum now naturally occurs on almost all continents.
It has long been recognized as a highly invasive species. Once introduced, P. setaceum can spread over large areas, thus modifying the characteristics and functioning of natural ecosystems, threatening local biodiversity, and also altering the carbon cycle, as documented in Hawaii and South Africa (Litton \& al., 2006; Cordell \& Sandquist, 2008; Rahlao \& al., 2010). In Sicily, P. setaceum is one of the most aggressive and rapid invaders of coastal and hilly areas; during the 70 years following its first introduction in Sicily, it has established and spread over many coastal areas up to 600 m.a.s.l. and especially on south-facing slopes within the thermo-Mediterranean belt (Brullo \& al., 2010). It frequently colonizes very disturbed and eutrophic habitats such as roadsides, railways, and urban wastelands. Pennisetum setaceum has also invaded $H$. hirta thermo-xeric grasslands and even the more mesophilous $A$. mauritanicus grasslands in some localities; in both cases, it has exhibited high competitive ability against native perennial species. Pennisetum setaceum has also a great phenotypic plasticity. hile it is able to withstand summer drought (and has already spread into sub-desertic environments), it also appears able to take rapid advantage of rainfall during the warmer months ( illiams \& Black, 1993; illiams \& al., 1995; Poulin \& al., 2007). These traits, combined with a fast growth rate after a disturbance event (e.g., fire) and long-distance seed dispersal, indicate that P. setaceum is likely to continue to spread into many other suitable localities in Sicily, with significant and long-lasting ecological consequences.

\section{Biomass prediction models for A. mauritanicus, H. hirta, and P. setaceum}

Field surveys were carried out during the spring of 2009. In each of the three studied localities, 20 individuals of different sizes for each species were selected by a stratified random sampling scheme and were removed from the soil with a weeding hoe. The weeding hoe was used carefully to obtain the root system as undamaged and complete as possible. After the plants were dug from the soil, the roots were roughly cleaned of soil, rock particles, and other impurities. The maximum length of the roots $(L r)$, the diameter of the root collar $(D)$, and the maximum height $(H)$ were immediately measured in the field with a pair of calipers and a measuring rod. Then, each plant was labelled with an identification code (including the date and the place of collection) and transported to the laboratory, where the root systems were thoroughly cleaned, and roots and shoots were oven dried for $3-4$ days at $60-65^{\circ} \mathrm{C}$. After drying, the roots were weighed to the nearest $0.01 \mathrm{~g}$, and the shoots were weighed to the nearest $0.1 \mathrm{~g}$.

Linear regression models that predict the aboveground (ag) and belowground (bg) biomass, and total biomass per individual for each species were developed using the measured morphometric attributes of individual plants $(L r, D$, and $H$ ) as potential predictors (independent variables). The predictors of the total biomass model were selected by the conventional stepwise method (Draper \& Smith, 1981), in which a critical value of $F$ was adopted in the process of inclusion equal to that of the process of elimination. The level of significance of critical $\mathrm{F}$ was set at 0.9 to ensure the selection of few predictors; the value of tolerance, which measures the stability of the correlation matrix, was set at 
0.001. The models for the prediction of ag and bg biomass included the same independent variables so that adding their predictions provides the same value predicted by the total biomass model.

The contribution of each of the three grassland species to biomass per hectare was estimated by assessing the coverage of each species within Sicilian grassland communities.

\section{RESULTS AND DISCUSSION}

\section{Biomass prediction models for A. mauritanicus, $H$. hirta, and P. setaceum}

The morphometric attributes measured for the selected individuals of the investigated species are all reported in Table 2. Because $A$. mauritanicus tufts are taller than those of the other two species, the higher values of biomass for A. mauritanicus, both above and belowground, were expected. Conversely, $H$. hirta plants were smaller than those of the other species. The mean root length of $P$. setaceum was comparable to that of $A$. mauritanicus, suggesting that an extensive root system may help to explain the invasion success of this alien species. The models for predicting the ag, $\mathrm{bg}$, and total biomass per individual of the three species are presented in Table 3. For all models, the residuals did not show trends, and their average was, as expected, close to zero. The predictive potential of the models was validated by a "leave-one-out" procedure, i.e., by the so-called deleted residuals (for each observation, a deleted residual was calculated by excluding the observation from the calculation of the regression coefficient; this procedure was repeated for each observation in turn).
The validation results (see Table 4) corroborate the ability of the established models to predict ag and total biomass of $A$. mauritanicus and $P$. setaceum; the models provided unbiased predictions (biases were less than $2 \%$ of the observed biomass means) and explained a high percentage of the variability of total biomass per individual of each species. The percent ratio between the mean of absolute deleted residuals and the mean of individual total biomass indicates the magnitude of the error when estimating the biomass of single individuals; this ratio was $33 \%$ for $A$. mauritanicus and $20 \%$ for $P$. setaceum. Although relatively high, these percentages are satisfactory if the biomass variability among the sampled individuals (biomass variation coefficient over 100\%) is taken into account.

In contrast, the models developed for $H$. hirta did not provide useful predictions: The percent ratio between the mean of the absolute deleted residuals and the mean total biomass was $53 \%$. No clear relationships were found between any measured morphometric attribute and the ag, bg, or total biomass per individual of this species. Hyparrbenia birta develops roots early and seems to develop a greater ratio of bg to ag biomass than the other species, probably as a specific adaptation to the xeric environments.

\section{Biomass values of grasslands}

ithin each of their respective communities, the average number of individuals per hectare was 15,000 for A. mauritanicus, 30,000 for $H$. birta (the smallest species), and 20,000 for $P$. setaceum. The number of individuals per hectare was multiplied by the mean dry weight per individual to estimate ag, bg, and total biomass per hectare for each of the three species (Table 5).

Table 2. Attributes for individuals of the three grass species.

\begin{tabular}{|c|c|c|c|c|}
\hline & & Minimum & Maximum & Mean \pm std. dev. \\
\hline \multirow{6}{*}{$\begin{array}{l}\text { Ampelodesmos } \\
\text { mauritanicus }\end{array}$} & diameter at root collar (cm) & 5 & 28 & $14.82 \pm 7.13$ \\
\hline & root length $(\mathrm{cm})$ & 17 & 50 & $32.86 \pm 7.95$ \\
\hline & height (cm) & 60 & 165 & $99.64 \pm 31.15$ \\
\hline & belowground biomass (g) & 4.69 & 96.40 & $24.94 \pm 23.85$ \\
\hline & aboveground biomass (g) & 44.8 & 2772.4 & $773.44 \pm 916.35$ \\
\hline & total biomass (g) & 56.92 & 2853.80 & $798.39 \pm 936.96$ \\
\hline \multirow[t]{6}{*}{ Hyparrhenia hirta } & diameter at root collar $(\mathrm{cm})$ & 2 & 21 & $12.50 \pm 6.20$ \\
\hline & root length $(\mathrm{cm})$ & 9 & 40 & $27.00 \pm 7.25$ \\
\hline & height (cm) & 31 & 79 & $59.45 \pm 12.22$ \\
\hline & belowground biomass (g) & 0.43 & 11.55 & $5.29 \pm 3.29$ \\
\hline & aboveground biomass (g) & 13.0 & 504.1 & $158.73 \pm 121.47$ \\
\hline & total biomass (g) & 14.08 & 510.06 & $164.01 \pm 122.93$ \\
\hline \multirow[t]{6}{*}{ Pennisetum setaceum } & diameter at root collar $(\mathrm{cm})$ & 3 & 21 & $11.07 \pm 5.46$ \\
\hline & root length $(\mathrm{cm})$ & 20 & 48 & $34.33 \pm 7.301$ \\
\hline & height (cm) & 23 & 79 & $49.00 \pm 14.33$ \\
\hline & belowground biomass (g) & 1.51 & 33.04 & $16.21 \pm 10.16$ \\
\hline & aboveground biomass (g) & 4.6 & 967.7 & $191.87 \pm 256.03$ \\
\hline & total biomass (g) & 6.11 & 1000.74 & $208.09 \pm 263.85$ \\
\hline
\end{tabular}


Table 3. Results of the regression analysis carried out to estimate the numerical coefficients of the predictive models $\left(r^{2}=\right.$ coefficient of determination; see $=$ standard error of the estimate, in $\mathrm{g}$ ).

\begin{tabular}{lccc}
\hline Species - biomass component & Model & $\mathbf{r}^{2}$ & see \\
\hline Am - ag & $A b=595.174+0.126373 * H^{2}$ & 0.906 & 293.1 \\
Am - bg & $B b=5.107+0.002776 * H^{2}$ & 0.645 & 14.8 \\
Am - total & $B t=600.281+0.129149 * H^{2}$ & 0.905 & 301.2 \\
$H h-\mathrm{ag}$ & $A b=125.486+4.781 * H$ & 0.231 & 109.4 \\
$H h-\mathrm{bg}$ & $B b=1.406+0.113 * H$ & 0.175 & 3.1 \\
$H h-$ total & $B t=126.891+4.893 * H$ & 0.237 & 110.3 \\
$P S-$ ag & $A b=6.415+0.0003395 * D^{2} * H^{2}$ & 0.958 & 54.4 \\
$P S-b g$ & $B b=10.324+0.0000108 * D^{2} * H^{2}$ & 0.614 & 6.5 \\
$P S-$ total & $B t=16.739+0.0003502 * D^{2 *} H^{2}$ & 0.960 & 54.5 \\
\hline
\end{tabular}

Key: Am = Ampelodesmos mauritanicus; $H$ h = Hyparrhenia hirta; $P s=$ Pennisetum setaceum; ag = aboveground biomass (g) per individual plant; $\mathrm{bg}=$ belowground biomass (g) per individual plant; total = total biomass (g) per individual plant; $H=$ maximum height in $\mathrm{cm} ; D=$ diameter at root collar in $\mathrm{cm}$. The units for the dependent variables are grams for every equation.

Table 4. Leave-one-out validation of the prediction models.

\begin{tabular}{|c|c|c|c|}
\hline $\begin{array}{l}\text { Species - biomass } \\
\text { component }\end{array}$ & $\begin{array}{l}\text { Mean of the deleted } \\
\text { residuals }(\mathrm{g})\end{array}$ & $\begin{array}{c}\text { Mean of the absolute deleted } \\
\text { residuals }(g)\end{array}$ & $\begin{array}{c}\text { Explained } \\
\text { variance (\%) }\end{array}$ \\
\hline$A m-a g$ & 9.9 & 254.8 & 87 \\
\hline$A m-b g$ & -0.8 & 11.8 & 17 \\
\hline$A m$ - total & 9.2 & 261.8 & 86 \\
\hline$H h-a g$ & -2.3 & 85.4 & 5 \\
\hline$H h-b g$ & -0.1 & 2.6 & 3 \\
\hline Ps - ag & 4.0 & 38.5 & 94 \\
\hline Ps - bg & -1.1 & 7.1 & 20 \\
\hline PS - total & 2.9 & 40 & 96 \\
\hline
\end{tabular}

Key: $A m=$ Ampelodesmos mauritanicus; $H$ h = Hyparrhenia hirta; $P s=$ Pennisetum setaceum; ag = aboveground biomass ( $\mathrm{g}$ ) per individual plant; $\mathrm{bg}=$ belowground biomass $(\mathrm{g})$ per individual plant; total = total biomass $(\mathrm{g})$ per individual plant.

Table 5. Phytosociological associations and mean biomass in grasslands on the study sites.

\begin{tabular}{llc}
\hline Locality & Phytosociological association & Biomass (Mg/ha) \\
\hline Cape Gallo, Mt. Pellegrino, Mt. Inici & Hyparrhenietum hirto-pubescentis (Hb-dominated grasslands) & 4.8 ag +0.2 bg \\
Cape Gallo, Mt. Pellegrino & Penniseto setacei-Hyparrhenietum birtae (Ps-dominated grasslands) & $3.8-4.8$ ag $+0.2-0.3$ bg \\
Cape Gallo, Mt. Pellegrino, Mt. Inici & $\begin{array}{l}\text { Helictotricho convoluti-Ampelodesmetum mauritanici } \\
\text { (A. mauritanicus-dominated grasslands) }\end{array}$ & 11.6 ag + 0.4 bg \\
\hline
\end{tabular}

Key: ag = aboveground biomass; $\mathrm{bg}=$ belowground biomass.

This approach, which uses phytosociological and biomass survey data, relies on the reasonable assumption that the total number of individuals of a species per hectare can be estimated by dividing its coverage per hectare (as indicated in the phytosociological relevés or plots) by its average crown area per individual. The estimated biomass per hectare was higher for $H$. birta than for $P$. setaceum because the native grass compensates for its lower biomass per individual with a larger number of individuals per unit area. It might be deduced that replacement of $H$. hirta by $P$. setaceum reduces the total carbon storage in the ecosystem; however, the xenophyte allocates more resources to the bg organs and therefore may contribute more than the native to a more stable and durable pool of carbon in these grasslands. The estimated $A$. mauritanicus biomass per hectare was substantially higher and was nearly as large as the lower value of biomass reported for Sicilian maquis (Costa \& La Mantia, 2005). On the other hand, biomass evaluation seems to be strongly affected by community structure. For example, an investigation at the Garraf Natural Park in Spain (Grigulis \& al., 2005) found relatively low values of ag biomass per hectare, ranging from 2 to $6 \mathrm{t} / \mathrm{ha}$ depending on the mean density of $A$. mauritanicus individuals and to the presence of a dense or a 
scattered dominant shrub layer. The mean value of biomass per hectare estimated for both $H$. hirta and P. setaceum falls within the ranges previously reported for Mediterranean grasslands. Several studies concerning these grasses have reported ag biomasses that range from approximately 1 (or even less) to just over 7 t/ha (Puerto \& al., 1990; Hector \& al., 1999; Cleemput \& al., 2004; Grigulis \& al., 2005; Vallejo \& al., 2006; Vázquez-de-Aldana \& al., 2006; Zarovali \& al., 2007; Golodets \& al., 2010; Salis \& al., 2010).

According to several sources, grasslands cover about 200,000 ha in Sicily (CLC 1990, 2000, 2006; AA. VV., 1996). If these data are combined with the biomass per hectare for each of the three perennial grass species, their total biomass in Sicily can be estimated to range from 0.98 to $2.40 \mathrm{Mt}$. Although this is clearly a rough assessment, it is useful and important because information on stand biomass of grasslands within the Mediterranean region is still scarce. Above all, this assessment indicates that such large-scale communities have a previously unrecognized potential to sequester carbon. Although biomass per hectare is considerable in the grassland communities, biomass per hectare is much greater in the pre-forest and forest formations, and was estimated to be about $19 \mathrm{Mt}$ for the entire woodland area of Sicily (Hofmann \& al., 2011).

\section{CONCLUSIONS}

This paper describes the first models that are able to predict the individual and community biomass of three perennial herbs that dominate central Mediterranean grasslands. The models should be useful for predicting the biomass of many other Mediterranean grasses with similar habit. Given the expected expansion of $\mathrm{C}_{4}$ grasses due to climatic warming (Mannetje, 2007), data concerning $H$. hirta and P. setaceum are very important for modelling the future carbon sequestration potential of Mediterranean xeric grasslands (Abberton \& al., 2009).

\section{ACKNOWLEDGEMENTS}

This work was financially supported by the MIURPRIN projects "The impacts of secondary succession processes on carbon storage in soil and biomass and on biodiversity and the role of dispersal centers and vectors for recolonization processes" and within the project "Climate change mitigation strategies in tree crops and forestry in Italy (CARBOTREES) (national head, Riccardo Valentini). e thank F. Castiglia, G. Provinzano, L. Scuderi, C. Di Leo, and the staff of the libraries of the Agricultural and the Botanical Faculties of the University of Palermo for their valuable collaboration. e are grateful to Bruce Jaffee for revising the English version of the manuscript.

\section{REFERENCES}

AA VV. 1996. Linee-guida del Piano Territoriale Paesistico Regionale, Regione Siciliana. Assessorato Beni Culturali e Ambientali e Pubblica Istruzione, Palermo.

Abberton, M., Conant, R. \& Batello, C. 2009. Grassland carbon sequestration: management, policy and economics. Proceedings of the Workshop on the role of grassland carbon sequestration in the mitigation of climate change 11. FAO, Integrated Crop Management, Rome.
Barbaro, L., Dutoit, T. \& Cozic, P. 2001. A six-year experimental restoration of biodiversity by shrub-clearing and grazing in calcareous grasslands of the French Prealps. Biodiversity and Conservation 10: 119-135. http://dx.doi.org/10.1023/A:1016629507196

Bonanomi, G., Caporaso, S. \& Allegrezza, M. 2006. Short-term effects of nitrogen enrichment, litter removal and cutting on a Mediterranean grassland. Acta Oecologica 30: 419-425. http://dx.doi.org/10.1016/j. actao.2006.06.007

Brullo, C., Brullo, S., Giusso del Galdo, G. \& al. 2010. The Lygeo-Stipetea class in Sicily. Annali di Botanica 0: 57-84. Available at: http://ojs.uniroma1.it/index.php/Annalidibotanica/article/view/9119.

Chejara, V.K., Kristiansen, P., halley, R.D.B. \& al. 2008. Factors affecting germination of Coolatai Grass (Hyparrhenia hirta). Weed Science 56: 543-548. http://dx.doi.org/10.1614/ S-07-163.1

Ciais, P., Soussana, J.F., Vuichard, N. \& al. 2010. The greenhouse gas balance of European grasslands. Biogeosciences Discussions 7: 5997-6050. http://dx.doi.org/10.5194/bgd-7-5997-2010

Cleemput, S., Muys, B., Kleinn, C. \& Janssens, M.J.J. 2004. Biomass estimation techniques for enclosures in a semi-arid area: a case study in Northern Ethiopia. Deutscher Tropentag, "Rural Poverty Reduction through Research for Development", October 5-7, 2004, Berlin, 6 pp. Available at: http://www.tropentag.de/2004/abstracts/ full/3.pdf.

CLC (Corine Land Cover). 1990. Scala 1:100.000. http://www.sin anet.isprambiente.it/it/sia-ispra/download-mais/corine-land-cover/ corine-land-cover-1990/view.

CLC (Corine Land Cover). 2000. Agenzia per la Protezione dell'ambiente e per i servizi tecnici (APAT) scala 1:100.000. http://www.sinanet. isprambiente.it/it/sia-ispra/download-mais/corine-land-cover/ corine-land-cover-2000/view.

CLC (Corine Land Cover). 2006. http://www.sinanet.isprambiente.it/it/ sia-ispra/download-mais/corine-land-cover/corine-land-cover-2006/ view.

Cordell, S. \& Sandquist, D.R. 2008. The impact of an invasive African bunchgrass (Pennisetum setaceum) on water availability and productivity of canopy trees within a tropical dry forest in Hawaii. Functional Ecology 22: 1008-1017. http://dx.doi.org/10.1111/ j.1365-2435.2008.01471.x

Corona, P., Barbati, A., Tomao, A. \& al. 2012. Land use inventory as framework for environmental accounting: an application in Italy. iForest 5: 204-209.

Costa, G. \& La Mantia, T. 2005. Il ruolo della macchia mediterranea nello stoccaggio del carbonio atmosferico. Forest@ 2:378-387. http://dx.doi. org/10.3832/efor0319-0020378

De Deyn, G.B., Shiel, R.S., Ostle, N.J. \& al. 2011. Additional carbon sequestration benefits of grassland diversity restoration. Journal of Applied Ecology 48: 600-608. http://dx.doi.org/10.1111/j.1365-2664.2010.01925.x

Dostálek, J. \& Frantík, T. 2008. Dry grassland plant diversity conservation using low-intensity sheep and goat grazing management: case study in Prague (Czech Republic). Biodiversity and Conservation 17: 1439-1454. http://dx.doi.org/10.1007/s10531-008-9352-1

Drago, A., Lo Bianco, B. \& Monterosso, I. 2002. Atlante climatologico della Sicilia. Assessorato Agricoltura e Foreste. Servizio Informativo Agrometereologico Siciliano. Regione Siciliana. Available at: www.sias. regione.sicilia.it.

Draper, N.R. \& Smith, H. 1981. Applied regression analysis. $2^{\text {nd }}$ ed. John iley, New York.

EC. 1992. Council Directive 92/43/EEC of 21 May 1992 on the conservation of natural habitats and of wild fauna and flora. Available at: http:// eur-lex.europa.eu/LexUriServ/LexUriServ.do?uri=CELEX:31992L00 43:EN:html.

FAO (Food and Agricultural Organization of the United Nations) 2006. FAO Statistical Yearbook. FAOSTAT.

Fierotti, G. 1988. Carta dei suoli della Sicilia (scala 1:250.000). Regione Siciliana, Ass. TT. AA. Univ. Palermo, Fac. Agraria, Ist. Agron. Generale, Cattedra di Pedologia.

FRA. 2010. Global Forest Resources Assessment. Available at: http://www. fao.org/forestry/fra/fra2010/en/ (accessed 20 July 2014).

Gilmanov, T.G., Soussana, J.F., Aires, L. \& al. 2007. Partitioning European grassland net ecosystem $\mathrm{CO}_{2}$ exchange into gross primary productivity and ecosystem respiration using light response function analysis. Agriculture Ecosystems and Environment 121: 93-120. http://dx.doi. org/10.1016/j.agee.2006.12.008

Golodets, C., Kigel, J. \& Sternberg, M. 2010. Recovery of plant species composition and ecosystem function after cessation of grazing in a 
Mediterranean grassland. Plant and Soil 329: 365-378. http://dx.doi. org/10.1007/s11104-009-0164-1

Grigulis, K., Lavorel, S., Davies, I.D. \& al. 2005. Landscape-scale positive feedbacks between fire and expansion of the large tussock grass, Ampelodesmos mauritanica in Catalan shrublands. Global Change Biology 11: 1042-1053. http://dx.doi.org/10.1111/j.1365-2486.2005. 00980.x

Grill, A., Knoflach, B., Cleary, D.F.R. \& Kati, V. 2005. Butterfly, spider, and plant communities in different land-use types in Sardinia, Italy. Biodiversity and Conservation 14: 1281-1300. http://dx.doi. org/10.1007/s10531-004-1661-4

Harrison, S., Inouye, B.D. \& Safford, H.D. 2003. Ecological Heterogeneity in the Effects of Grazing and Fire on Grassland Diversity. Conservation Biology 17: 837-845.http://dx.doi.org/10.1046/j.1523-1739.2003.01633.x

Hector, A., Schmid, B., Beierkuhnlein, C. \& al. 1999. Plant diversity and productivity experiments in European grasslands. Science 286 1123-1127. http://dx.doi.org/10.1126/science.286.5442.1123

Hofmann, A., Cibella, R., Bertani, R. \& al. 2011. Strumenti conoscitivi per la gestione delle risorse forestali della Sicilia. Sistema Informativo Forestale. Assessorato Territorio e Ambiente Regione Siciliana.

Hungate, B.A., Holland, E.A., Jackson, R.B. \& al. 1997. The fate of carbon in grasslands under carbon dioxide enrichment. Nature 388: 576-579. http://dx.doi.org/10.1038/41550

Janssens, I.A., Freibauer, A., Ciais, P. \& al. 2003. Europe's terrestrial biosphere absorbs 7 to $12 \%$ of European anthropogenic $\mathrm{CO} 2$ emissions Science 300: 1538-1542. http://dx.doi.org/10.1126/science.1083592

Janssens, I.A., Freibauer, A., Schlamadinger, B. \& al. 2005. The carbon budget of terrestrial ecosystems at country-scale, a European case study. Biogeosciences 2: 15-26. http://dx.doi.org/10.5194/bg-2-15-2005

Jones, M.B. 2010. Potential for carbon sequestration in temperate grassland soils. In: Abberton, M., Conant, R. \& Batello, C. (eds.), Grassland carbon sequestration: management, policy and economics. Proceedings of the Workshop on the role of grassland carbon sequestration in the mitigation of climate change. Integrated Crop Management 11. FAO, Roma, pp. 18.

Litav, M. 1972. Factors determining the distribution pattern of Hyparrhenia birta (L.) Stapf. on different expositions and slopes in the Judean hills. Israel Journal of Botany 21: 76-89.

Litton, C.M., Sandquist, D.R. \& Cordell, S. 2006. Effects of non-native grass invasion on aboveground carbon pools and tree population structure in a tropical dry forest of Hawaii. Forest Ecology and Management 231: 105-113. http://dx.doi.org/10.1016/j.foreco.2006. 05.008

Mannetje ('t), L. 2007. The role of grasslands and forests as carbon stores. Tropical Grasslands 41: 50-54.

McArdle, S.L., Nadolny, C. \& Sindel, B.M. 2004. Invasion of native vegetation by Coolatai grass Hyparrhenia birta: impacts on native vegetation and management implications. Pacific Conservation Biology 10: 49-56.

Mc illiam, J.R., Shanker, K. \& Knox, R.B. 1970. Effects of temperature and photoperiod on growth and reproductive development in Hyparrhenia birta. Australian Journal of Agricultural Research 21: 557-569. http:// dx.doi.org/10.1071/AR9700557

Mingo, A. \& Mazzoleni, S. 1997. Ecophysiology of five Mediterranean perennial grasses: I) Effects of shade, water stress and defoliation on growth and allocation. Plant Biosystems 131: 207-215. http://dx.doi.org /10.1080/11263504.1997.10654183

Minissale, P. 1995. Studio fitosociologico delle praterie ad Ampelodesmos mauritanicus della Sicilia. Colloques Phytosociologique XXI: 615-652.

Noy-Meir, I. 1995. Interactive effects of fire and grazing on structure and diversity of Mediterranean grasslands. Journal of Vegetation Science 6: 701-710. http://dx.doi.org/10.2307/3236441

Noy-Meir, I. \& Oron, T. 2001. Effects of grazing on geophytes in Mediterranean vegetation. Journal of Vegetation Science 12: 749-760. http://dx.doi.org/10.2307/3236862

Öckinger, E. \& Smith, H.G. 2007. Semi-natural grasslands as population sources for pollinating insects in agricultural landscapes. Journal of Applied Ecology 44:50-59. http://dx.doi.org/10.1111/j.1365-2664.2006. 01250.x

Pärtel, M., Bruun, H.H. \& Sammul, M. 2005. Biodiversity in temperate European grasslands: origin and conservation. In: Lillak, R., Viiralt, R., Linke, A. \& Geherman, V. (eds.), Integrating efficient grassland farming and biodiversity. Proceedings of the $13^{\text {th }}$ International Occasional Symposium of the European Grassland Federation. Tartu, Estonia 29-31 August 2005. Greif printhouse, Tartu, pp. 16.
Parton, .J., Scurlock, J.M.O., Ojima, D.S., Schimel, D.S. \& Hall, D.O. 1995. Impact of climate change on grassland production and soil carbon worldwide. Global Change Biology 1: 13-22. http://dx.doi. org/10.1111/j.1365-2486.1995.tb00002.x

Pasta, S., Badalamenti, E. \& La Mantia, T. 2010. Tempi e modi di un'invasione incontrastata: Pennisetum setaceum (Forssk.) Chiov. (Poaceae) in Sicilia. Il Naturalista siciliano 34: 487-525.

Poulin, J., Sakai, A.K., eller, S.G. \& Nguyen, T. 2007. Phenotypic plasticity, precipitation and invasiveness in the fire-promoting grass Pennisetum setaceum (Poaceae). American Journal of Botany 94: 533 541. http://dx.doi.org/10.3732/ajb.94.4.533

Pucheta, E., Cabido, M., Díaz, S. \& Funes, G. 1998. Floristic composition, biomass, and aboveground net plant production in grazed and protected sites in a mountain grassland of central Argentina. Acta Oecologica 19: 97-105. http://dx.doi.org/10.1016/ S1146-609X(98)80013-1

Puerto, A., Rico, M., Matías, M.D. \& García J.A. 1990. Variation in structure and diversity in Mediterranean grasslands related to trophic status and grazing intensity. Journal of Vegetation Science 1: 445-452. http:// dx.doi.org/10.2307/3235777

Pykälä, J. 2003. Effects of restoration with cattle grazing on plant species composition and richness of semi-natural grasslands. Biodiversity and Conservation 12: 2211-2226. http://dx.doi.org/10.1023/A 1024558617080

Pykälä, J. 2004. Cattle grazing increases plant species richness of most species trait groups in mesic semi-natural grasslands. Plant Ecology 175: 217-226. http://dx.doi.org/10.1007/s11258-005-0015-y

Rahlao, S.J., Esler, K.J., Milton, S.J. \& Barnard, P. 2010. Nutrient Addition and Moisture Promote the Invasiveness of Crimson Fountaingrass (Pennisetum setaceum). Weed Science 58: 154-159. http://dx.doi. org/10.1614/ S-09-091.1

Robinson, D. 2007. Implications of a large global root biomass for carbon sink estimates and for soil carbon dynamics. Proceedings of the Royal Society B: Biological Sciences 274: 2753-2759. http://dx.doi. org/10.1098/rspb.2007.1012

Salis, L., Marrosu, M., Bagella, S. \& al. 2010. Grassland management, forage production and plant biodiversity in a Mediterranean grazing system. In: Porqueddu, C. \& Ríos, S. (eds.), Options Méditerranéennes, A $N^{\circ}$. 92. The contributions of grasslands to the conservation of Mediterranean biodiversity. CIHEAM/CIBIO/FAO/SEEP, Zaragoza, pp. 181-185.

Scurlock, J.M.O. \& Hall, D.O. 1998. The global carbon sink: a grassland perspective. Global Change Biology 4: 229-233. http://dx.doi. org/10.1046/j.1365-2486.1998.00151.x

Tuba, Z. \& Kaligarič, M. 2008. Grassland ecology in changing climate and land use. Community Ecology 9(suppl. 1): 3-12. http://dx.doi. org/10.1556/ComEc.9.2008.S.3

UNESCO (United Nations Educational, Scientific, and Cultural Organization). 1973. International Classification and Mapping of Vegetation. Series 6. Ecology and Conservation. United Nations, Paris, France.

Vallejo, R., Aronson, J., Pausas, J.G. \& Cortina, J. 2006. Restoration of Mediterranean woodlands. In: Van Andel, J. \& Aronson, J (eds.), Restoration ecology: The New Frontier. Blackwell Science, Oxford, UK.

Vázquez-de-Aldana, B.R., García-Ciudad, A. \& García-Criado, B. 2006. Biomass production and protein content of semiarid grasslands in western Spain over a 20-years period. In: Lloveras, J., GonzálezRodríguez, A., Vázquez-Yáñez, O., Piñeiro, J., Santamaría, O., Olea, L. \& Poblaciones, M.J. (eds.), Sustainable Grassland Productivity. Grassland Science in Europe, vol. 11. Artes Gráficas Marcipa: Badajoz, Spain.

Verdù, J.R., Crespo, M.B. \& Galante, E. 2000. Conservation strategy of a nature reserve in Mediterranean ecosystems: The effects of protection from grazing on biodiversity. Biodiversity and Conservation 9: 1707. 1721. http://dx.doi.org/10.1023/A:1026506725251

Vilà, M., Lloret, F., Ogheri, E. \& Terradas, J. 2001. Positive fire-grass feedback in Mediterranean Basin woodlands. Forest Ecology and Management 147: 3-14. http://dx.doi.org/10.1016/S0378-1127(00) 00435-7

allis de Vries, M.F., Poschlod, P. \& illems, J.H. 2002. Challenges for the conservation of calcareous grasslands in northwestern Europe: Integrating the requirements of flora and fauna. Biological Conservation 104: 265-273. http://dx.doi.org/10.1016/S0006$3207(01) 00191-4$ 
illems, J.H. 1983. Species composition and above ground phytomass in chalk grassland with different management. Plant Ecology 52: 171-180. http://dx.doi.org/10.1007/BF00044994

illiams, D.G. \& Black, R.A. 1993. Phenotypic variation in contrasting temperature environments: Growth and photosynthesis in Pennisetum setaceum from different altitudes on Hawaii. Functional Ecology 7: 623633. http://dx.doi.org/10.2307/2390140

illiams, D.G., Mack, R.N. \& Black, R.A. 1995. Ecophysiology of introduced Pennisetum setaceum on Hawaii: The role of phenotypic plasticity. Ecology 26: 1569-1584. http://dx.doi.org/10.2307/ 1938158

Young, J., att, A., Nowicki, P. \& al. 2005. Towards sustainable land use: identifying and managing the conflicts between human activities and biodiversity conservation in Europe. Biodiversity and Conservation 14: 1641-1661. http://dx.doi.org/10.1007/s10531-004-0536-z

Zarovali, M.P., Yiakoulaki, M.D. \& Papanastasis, V.P. 2007. Effects of shrub encroachment on herbage production and nutritive value in semi-arid Mediterranean grasslands. Grass and Forage Science 62:355-363. http:// dx.doi.org/10.1111/j.1365-2494.2007.00590.x

Associated Editor: Ricarda Riina Received: 24-XI-2014 Accepted: 31-V-2015 